Journal of the Society for the Study of Architecture in Canada Le Journal de la Société pour l'étude de l'architecture au Canada

\title{
Heritage Value in Ottawa's Dominion-Chalmers United Church: History, Community, Sight, and Sound
}

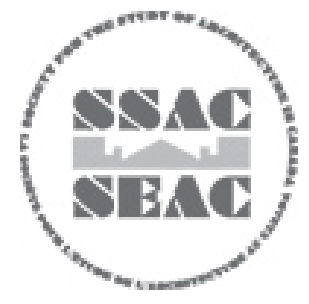

Natalie Anderson Rathwell

Volume 43, numéro 1, 2018

Religious Architecture in Canada

URI : https://id.erudit.org/iderudit/1049407ar

DOI : https://doi.org/10.7202/1049407ar

Aller au sommaire du numéro

Éditeur(s)

SSAC-SEAC

ISSN

2563-8696 (numérique)

Découvrir la revue

Citer cet article

Rathwell, N. A. (2018). Heritage Value in Ottawa's Dominion-Chalmers United Church: History, Community, Sight, and Sound. Journal of the Society for the Study of Architecture in Canada / Le Journal de la Société pour l'étude de l'architecture au Canada, 43(1), 47-56. https://doi.org/10.7202/1049407ar 


\section{HERITAGE VALUE IN OTTAWA'S DOMINION-CHALMERS UNITED CHURCH: HISTORY, COMMUNITY, SIGHT, AND SOUND}

NATALIE ANDERSON RATHWELL is currently a doctoral student in art history and visual culture at York University. She holds a master's and bachelor's degree in art history from Carleton University. Her main areas of interest are nineteenth-century religious architecture in Canada, medieval architecture, and multisensory perception in religious spaces, including issues of synaesthesia. In her doctoral dissertation, she intends to examine churches designed by Canadian architect Alexander C. Hutchison through the lens

of sensory studies.

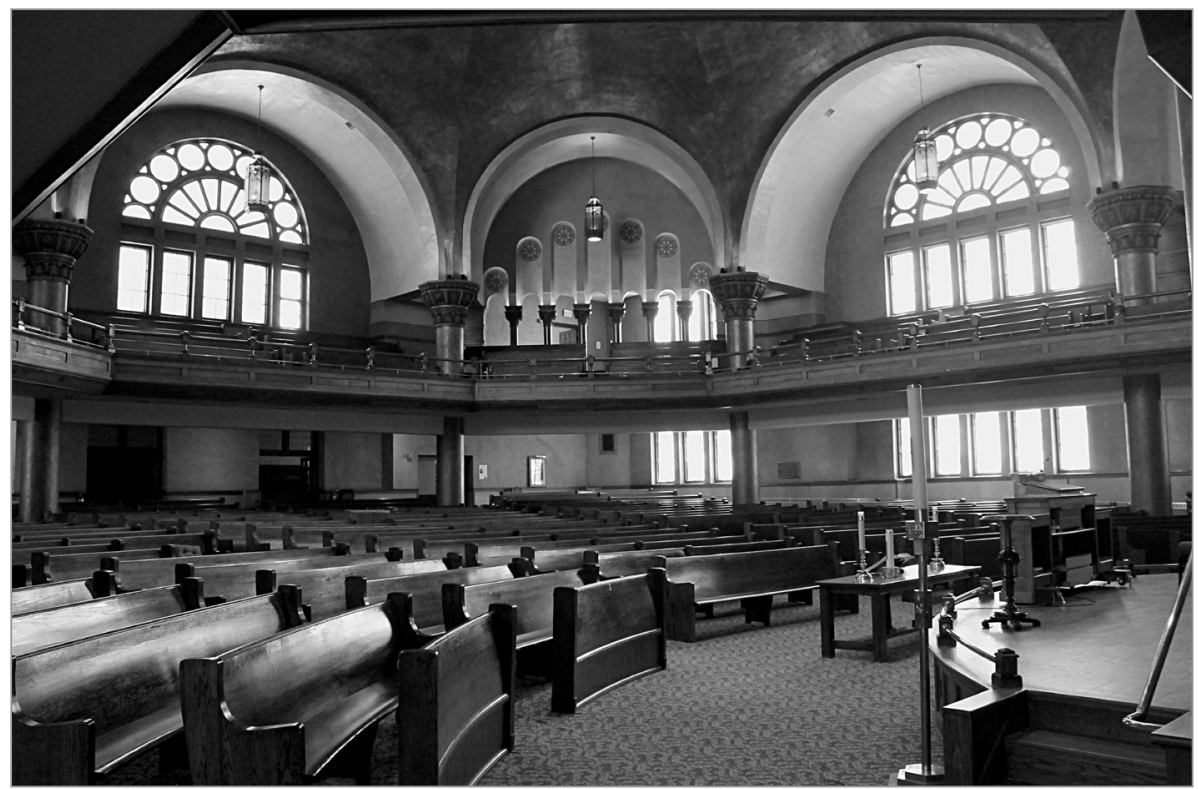

FIG. 1. DOMINION-CHALMERS UNITED CHURCH, SANCTUARY INTERIOR LOOKING TOWARD THE CORNER OF COOPER AND O'CONNOR STREETS, OTTAWA. | NATALIE ANDERSON RATHWELL, 2017.

\author{
$>$ NATALIE ANDERSON \\ RATHWELL ${ }^{1}$
}




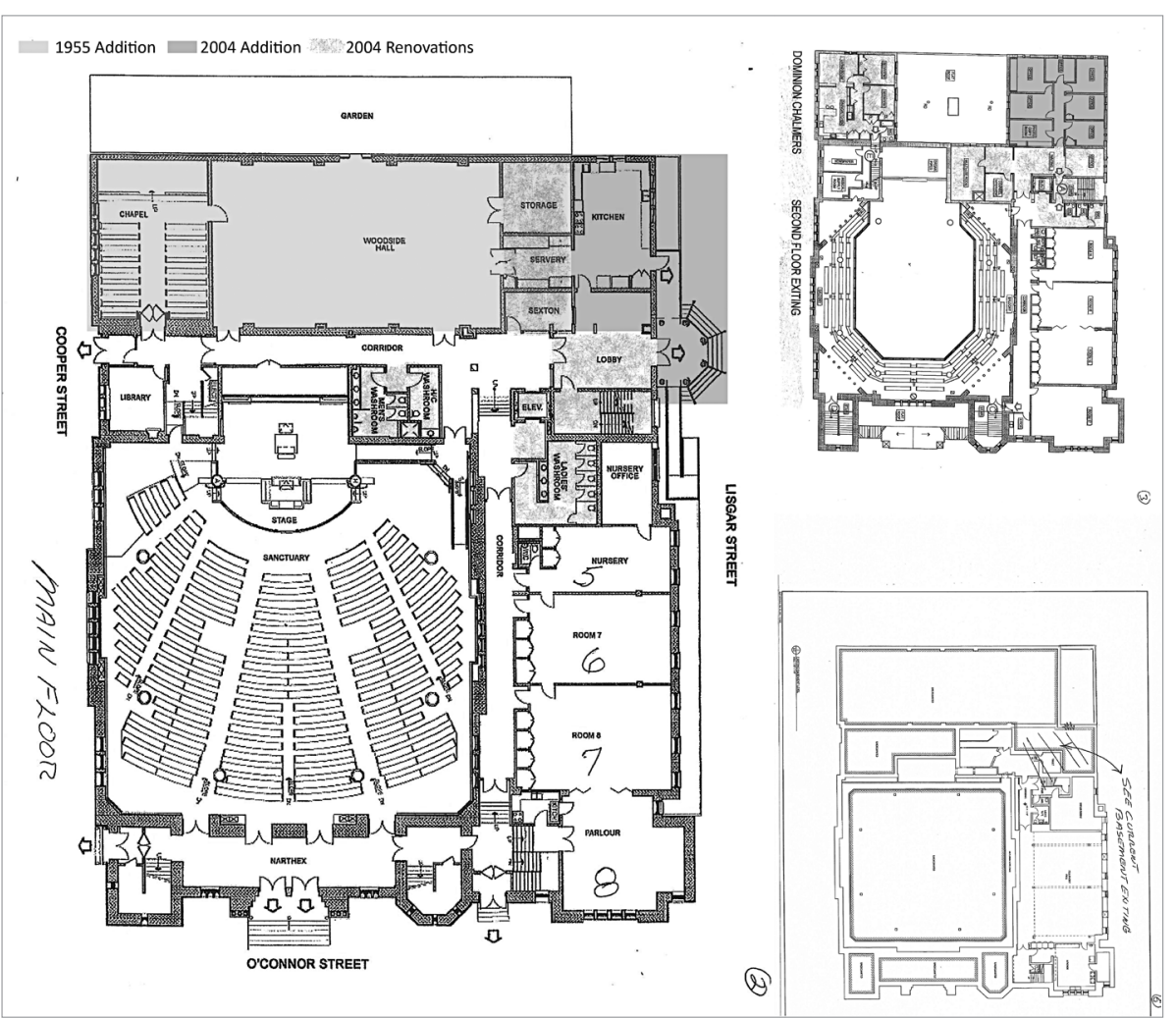

FIG. 2. PLAN OF DOMINION-CHALMERS, 2000, ROBERTSON MARTIN ARCHITECTS. | COURTESY OF DOMINION-CHALMERS UNITED CHURCH. HIGHLIGHTING AND NOTATIONS TO SHOW ADDITIONS BY NATALLE ANDERSON RATHWELL.

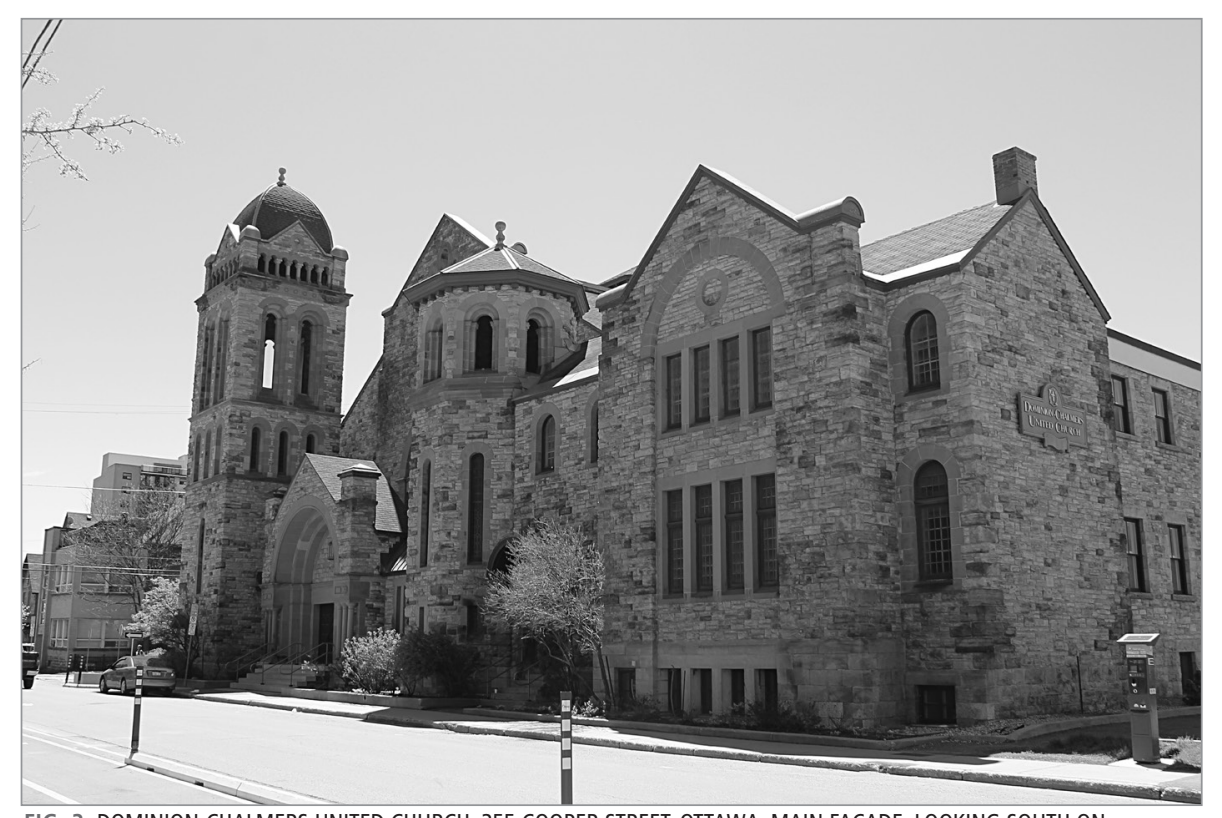

FIG. 3. DOMINION-CHALMERS UNITED CHURCH, 355 COOPER STREET, OTTAWA, MAIN FAÇADE, LOOKING SOUTH ON O'CONNOR STREET. | NATALLE ANDERSON RATHWELL, 2017.

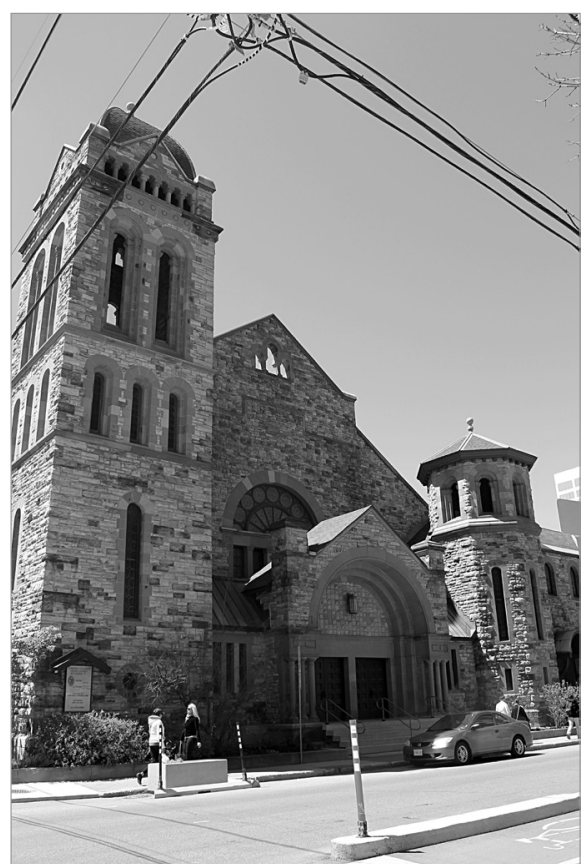

FIG. 4. DOMINION-CHALMERS, LOOKING NORTH ON O'CONNOR STREET. | NATALE ANDERSON RATHWELL, 2017.

\section{THE BUILDING}

The religious complex of DominionChalmers consists of a large church sanctuary, chapel, church halls, classrooms, parlours and administrative offices, a parking lot, and a midsized garden. This complex, which forms one integrated building unit, takes up one end of the city block surrounded by Cooper, O'Connor, and Lisgar streets (fig. 2). The original 1909 lot was 150 feet on O'Connor by 135 feet and 8 inches on Cooper, and has since been expanded to the west and north. ${ }^{2}$ The façade of the church is located along the west side of O'Connor (figs. 3-4). Looking north from this position, the West Block of Parliament is visible at the end of the street. This assessment of heritage value will address primarily the church sanctuary and the original parts of the building exterior. ${ }^{3}$ Significant additions and renovations were made to the auxiliary spaces of the church in 1955, precipitated in part 
by a fire in the Sunday school hall, which was the first section of the building to be constructed (fig. 5). Further additions as well as restoration work-which included cleaning and repointing the stonework, reopening the windows in the dome, new glass for the dome windows, and repainting the sanctuary to reflect descriptions of its original colours-were completed between 2000 and 2004.

As a property evaluation of the site outlines, "The exterior of the church [is] clad in Nepean sandstone, with Miramichi sandstone trim and a limestone base."4 The Nepean sandstone has a hammerdressed finish, which lends an intentionally rusticated appearance to the building. The Miramichi sandstone, meanwhile, is finished with a smooth ashlar dressing. It is of a uniform sandy blond colour, which complements the more mottled Nepean sandstone. The face of the church on O'Connor Street consists of a main entryway with two sets of double doors, flanked on either side by a square and octagonal tower, as well as the extension of the façade to the north, encompassing the Sunday school hall. The church's architect, Alexander Cowper Hutchison, described the building as follows (fig. 6):

\footnotetext{
The building is designed after the Romanesque Architecture of Southern France adapted to modern requirements. The auditorium of the church is square in plan with an octagon inscribed and has a vaulted ceiling and dome supported on eight massive columns. The choir, organ and pulpit occupy a recess at the rear of the auditorium, and on three sides of the church is a gallery ... a vestibule [extends] across the whole front of the church. ${ }^{5}$
}

Other church documents describe the building as having "Romanesque and Byzantine influences in its layout and decoration." 6

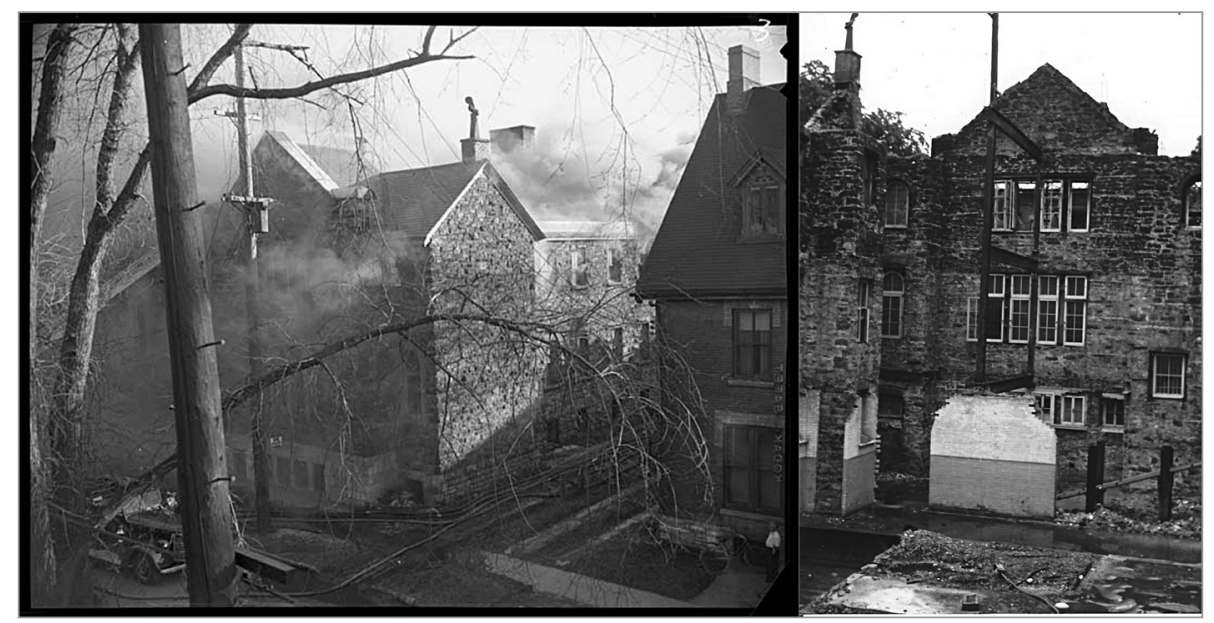

FIG. 5. SUNDAY SCHOOL HALL FIRE, EXTERIOR AND GUTTED INTERIOR, DOMINION-CHALMERS UNITED CHURCH. | PHOTOGRAPHER UNKNOWN. COURTESY OF DOMINION-CHALMERS UNITED CHURCH ARCHIVES.

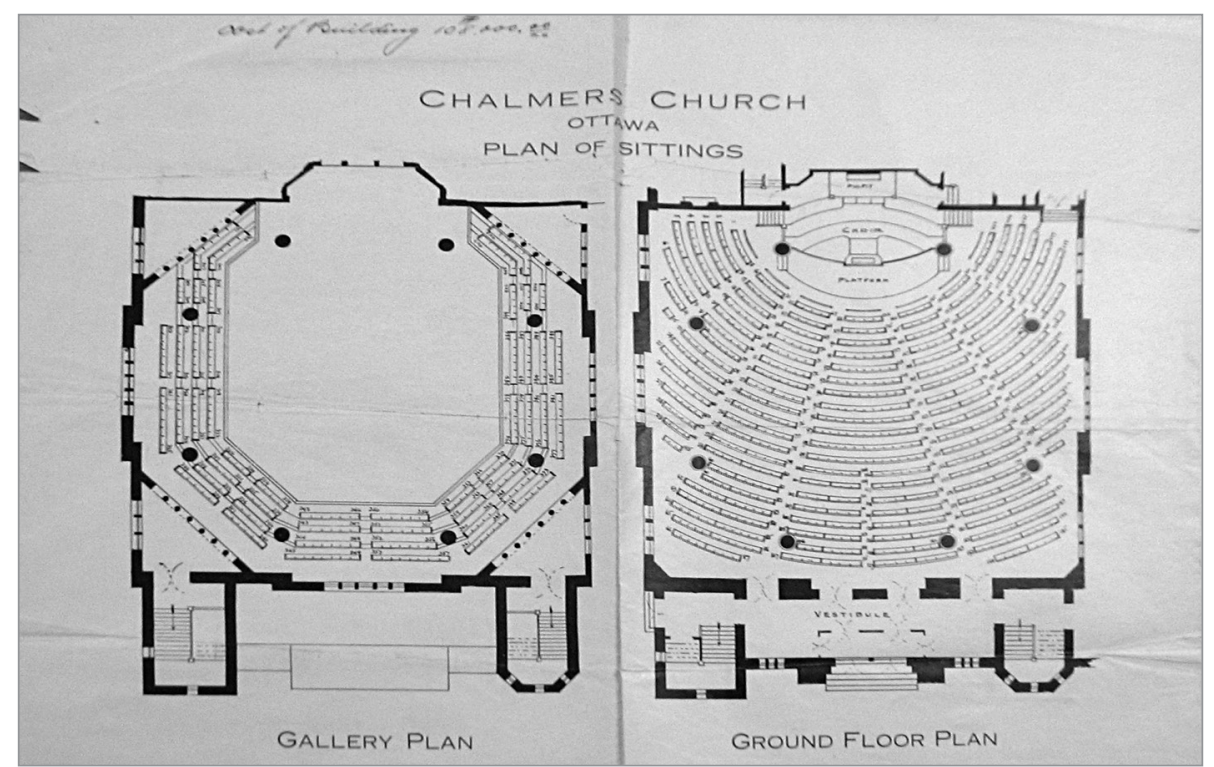

FIG. 6. CHALMERS CHURCH, OTTAWA, ORIGINAL SEATING PLAN. | COURTESY OF DOMINION-CHALMERS UNITED CHURCH ARCHIVES.

\section{"THE CHURCH" - THE LIFE OF A CONGREGATION HISTORIC AND CULTURAL VALUE}

In terms of the Church's historic and cultural value, the ongoing trajectory of Dominion-Chalmers' life in its community corresponds closely to the progression of Protestantism in Canada as a whole, and Ottawa specifically. ${ }^{7}$ The building was constructed as Chalmers Presbyterian
Church with its cornerstone laid in 1912 Chalmers is a child of one of two original Presbyterian churches in Bytown, both formed before $1865 .{ }^{8}$ The older of these two, St. Andrew's, was associated with the Established Church of Scotland. ${ }^{9}$ The second, Knox Presbyterian, with which we are concerned, was associated with the Presbyterian Church in Canada. Both of these Presbyterian communities persist today. 


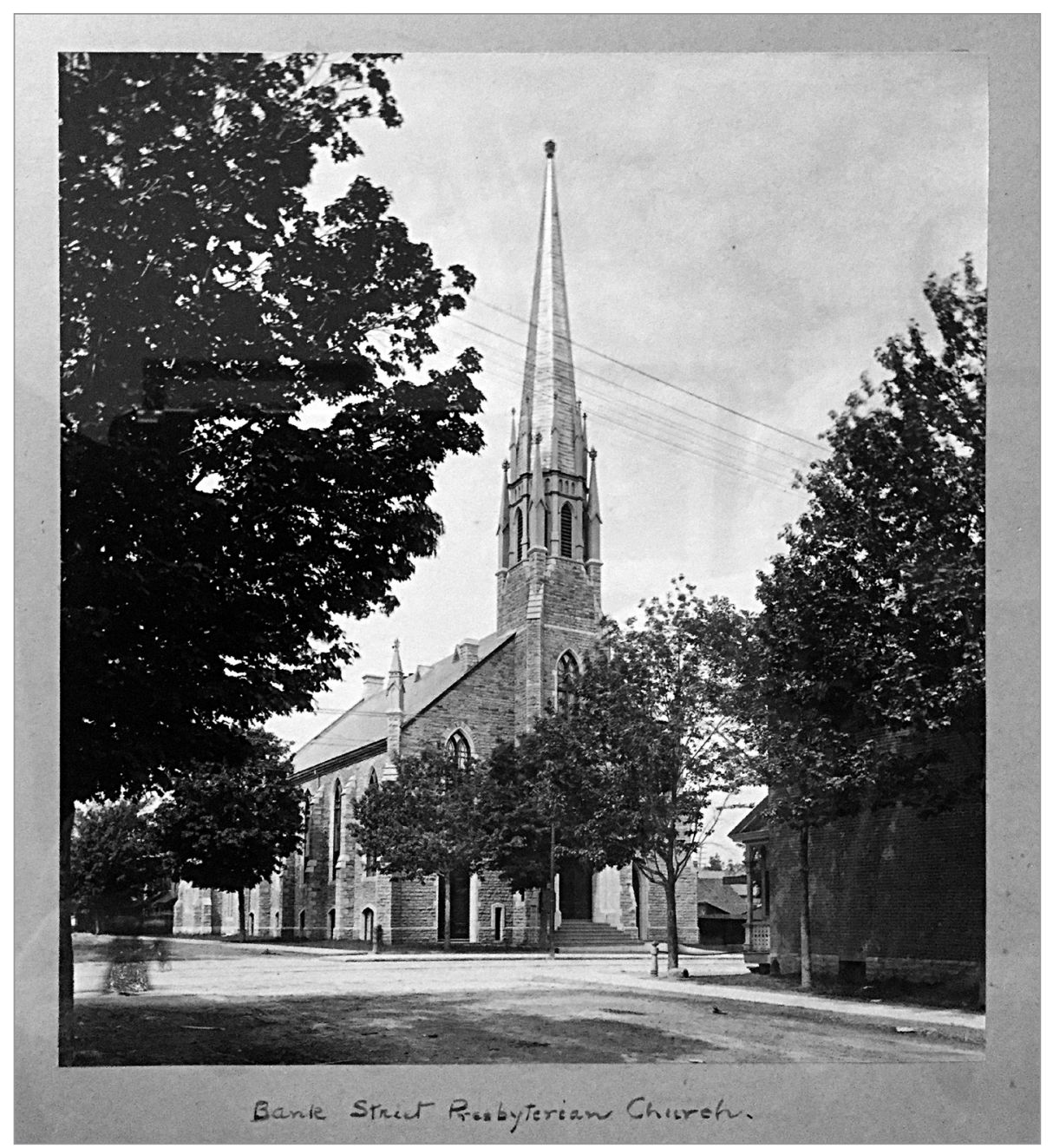

FIG. 7. BANK STREET PRESBYTERIAN CHURCH, OTTAWA (DEMOLISHED). | PHOTOGRAPHER UNKNOWN. COURTESY OF DOMIIION-CHALMERS UNITED CHURCH ARCHIVES.

Knox was eventually unable to accommodate a growing congregation and so volunteers were selected to establish a new church. Twenty-five families became the founding members of a new congregation. Among these, nineteen persons were church members, including three church elders. ${ }^{10} \mathrm{~A}$ new building lot was purchased at Bank Street and Slater."1 Bank Street Presbyterian Church was founded, and a substantial Gothic Revival stone church was built by 1869 (fig. 7). By 1907, the growth of the congregation was straining the capacity of this building. ${ }^{12}$ With heavy traffic and noise from the streetcars then in the history of Protestantism in Canada as an organizer of Church Union, and was the Moderator (elected presiding officer) of the resulting United Church of Canada between 1938 and 1940. ${ }^{14}$ The United Church was born out of an amalgamation of Canadian Presbyterian, Methodist, and Congregationalist churches. In 1925 Chalmers Presbyterian voted for union, with 651 in favour and 197 opposed, and transitioned to Chalmers United..$^{15}$ An influx of members from churches that had not voted for union made Chalmers a very strong and influential congregation within the United Church. ${ }^{16}$ Chalmers United Church became Dominion-Chalmers United Church in 1962. In combining congregations, the historical significance of Ottawa's Dominion United (formerly Methodist) can be said to have been taken on in part by Chalmers.

On the church's $110^{\text {th }}$ anniversary, an article in the Montreal Gazette referred to Dominion Methodist Church as "the "Mother Church" of Methodism."17 As a congregation, Dominion Methodist was the oldest Protestant church in Ottawa. In 1816, one Reverend Israel Chamberlayne "came up the river by canoe to Hull where he preached to the soldiers and settlers who gathered in the home of Squire Wright." ${ }^{18}$ Church historian Audrey Hilborn recounts that "From these class meetings, representatives were sent to Bytown in 1826, to organize a class and erect a chapel. It was called the Methodist Mission Chapel, the first religious house in Bytown (two years older than St. Andrew's Presbyterian, next in Seniority)." 19 A basic history of St. Andrew's confirms this sequence of events. ${ }^{20}$ John Burrows, a civil engineer who worked on the Rideau Canal with Lieutenant Colonel John By, allowed the use of his land for the construction of the chapel. ${ }^{21}$ Another small Methodist church was built in Upper Town in 1830.22 These 
congregations then amalgamated in 1852 to build a stone church on Dominion's final site on Metcalfe Street. To accommodate greater numbers, this stone church was demolished and rebuilt in 1874, dedicated as Dominion Methodist Church.

As at Chalmers, the congregation at Dominion voted for Church Union in 1925. The two churches were then of one faith and already integrated in their communities when the calamitous fire of 1961 destroyed Dominion and almost all of its contents. ${ }^{23}$ By 1962, it was determined that the church would not be rebuilt, and Chalmers offered amalgamation. Six stained-glass windows that were saved from the fire were incorporated into the north wall of the renamed DominionChalmers sanctuary. These are accompanied by a new window dedicated to the memory of the fire (fig. 8).

Of the many figures associated with the history of Dominion, one important historical association that was carried forward into the new Dominion-Chalmers United Church is represented in a plaque saved from the fire. Rediscovered in the early 2000s based on the persistence of two parishioners, the plaque is dedicated to the memory of Alexis Helmer by his parents. ${ }^{24}$ Helmer was a soldier in the First World War and a friend of Lieutenant Colonel John McCrae. It was after presiding over Helmer's funeral that McCrae penned his famous poem, In Flanders Fields.

While membership numbers seem to indicate a large congregation in the early 1960 s, by the end of the decade, attendance at Dominion-Chalmers United had evidently dropped sufficiently to cause concern for funding. ${ }^{25}$ This follows the pattern of many United Churches in Canada coinciding with changes in society, including the vast growth of the suburbs.

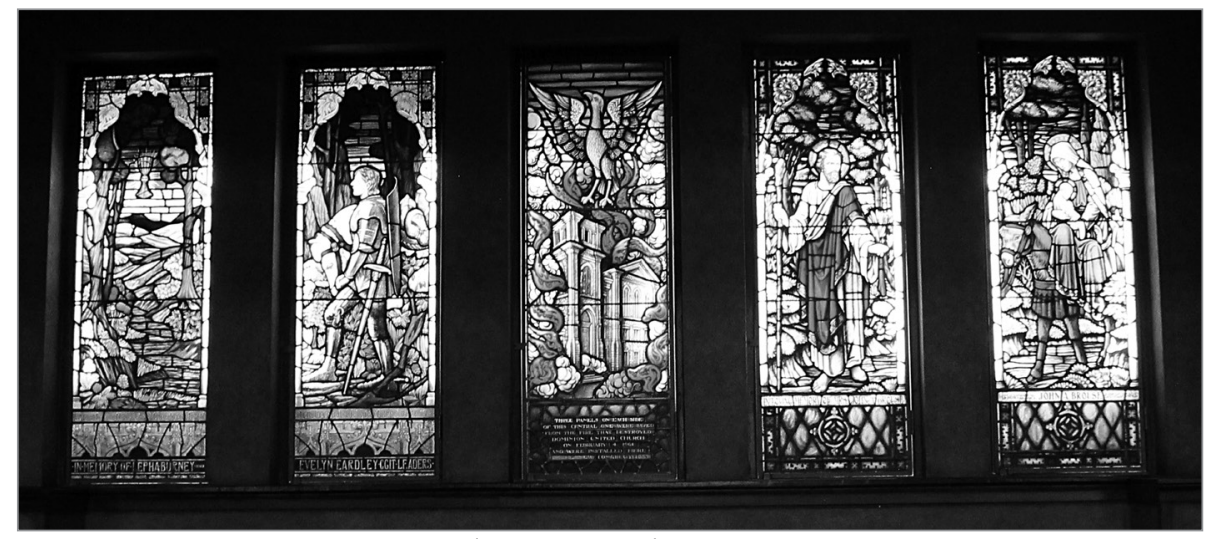

FIG. 8. FOUR OF SIX STAINED-GLASS WINDOWS (NOW LIGHT BOXES) SALVAGED FROM THE DOMINION CHURCH FIRE, WITH NEW COMMEMORATIVE WINDOW AT CENTRE. | NATALIE ANDERSON RATHWELL, 2017.

\section{SOCIAL AND SPIRITUAL VALUE}

Historic and cultural value, as just described, are constituted by "associations that a place has with past events and historical themes, as well as its capacity to evoke a way of life or a memory of the past." ${ }^{26}$ Conversely, social value "considers the meanings attached to a place by a community in the present time," 27 while "spiritual value is ascribed to places with religious or spiritual meanings for a community or a group of people." ${ }^{28}$ Spiritual value can refer to both past and present associations. ${ }^{29}$

Dominion-Chalmers was built as a church and continues to function as such. This function is expected to continue, as the ongoing use of certain spaces and time slots by the congregation is a point of negotiation in the sale of the building. ${ }^{30}$ It is a longstanding spiritual venue within the downtown cityscape. Socially, Dominion-Chalmers houses various community groups associated with the church and also acts as a venue for events significant to the wider Ottawa community. In particular, the church sanctuary is used as a main stage for the annual Ottawa Chamber Music Festival, among other performances.

\section{AESTHETIC VALUE - BUILDING FOR THE SENSES}

This brings us to perhaps the most significant contributing factor to the heritage value of Dominion-Chalmers. The most traditional of the sub-categories for heritage designation by the Canadian Register, and present in spades, is the church's aesthetic merit. At length:

\footnotetext{
Aesthetic value refers to the sensory qualities of a historic place (seeing, hearing, touching, smelling and tasting] in the context of broader categories of design and tradition. A place may have aesthetic significance because it evokes a positive sensory response, or because it epitomizes a defined architectural style or landscape concept . . . [lt] may reflect a particular style or period of construction or craftsmanship, or represent the work of a well-known architect, planner, engineer or builder. ${ }^{31}$
}

Dominion-Chalmers displays visual and auditory significance, is representative of a design tradition and defined architectural style, and is a work by a significant Canadian architect. Visually interesting both in its exterior and interior, the church's use of materials, textures, colours, and arrangement of space are aesthetically 


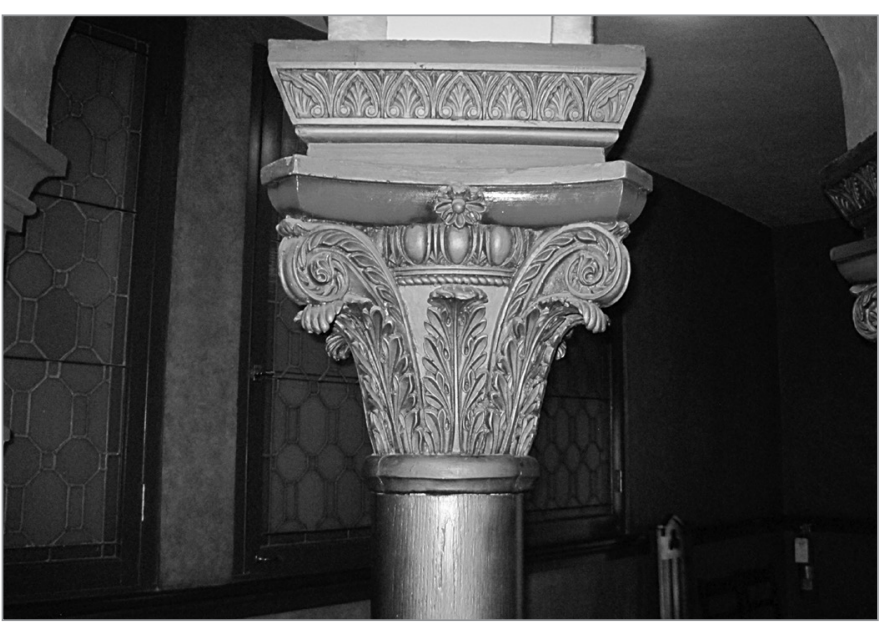

FIG. 9. DETAIL, CORINTHIAN CAPITAL, GALLERY ENTRANCE, DOMINION-CHALMERS SANCTUARY. | NATALIE ANDERSON RATHWELL, 2013.

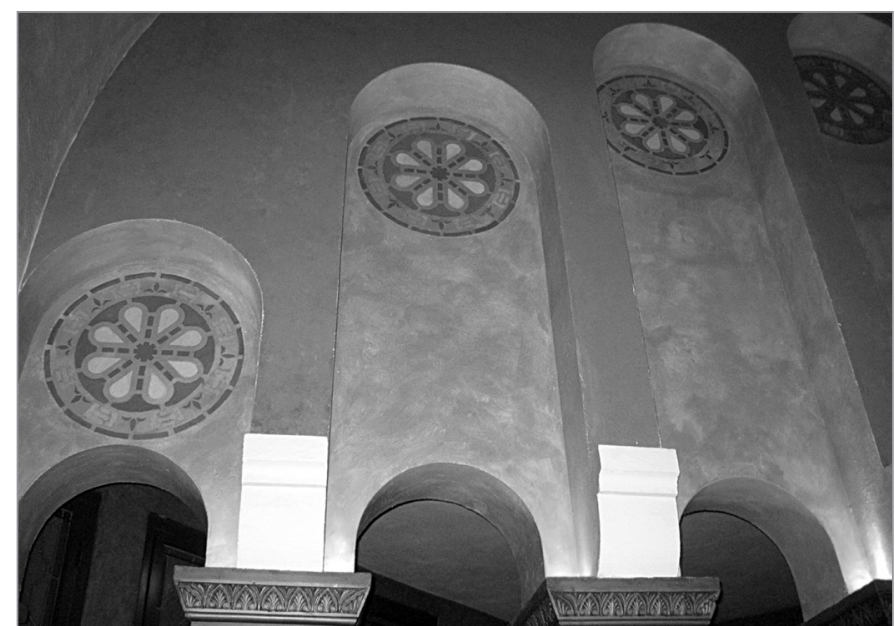

FIG. 11. ORIGINAL STENCIL WORK ABOVE GALLERY ENTRANCES, DOMINION CHALMERS.| NATALIE ANDERSON RATHWELL, 2013.

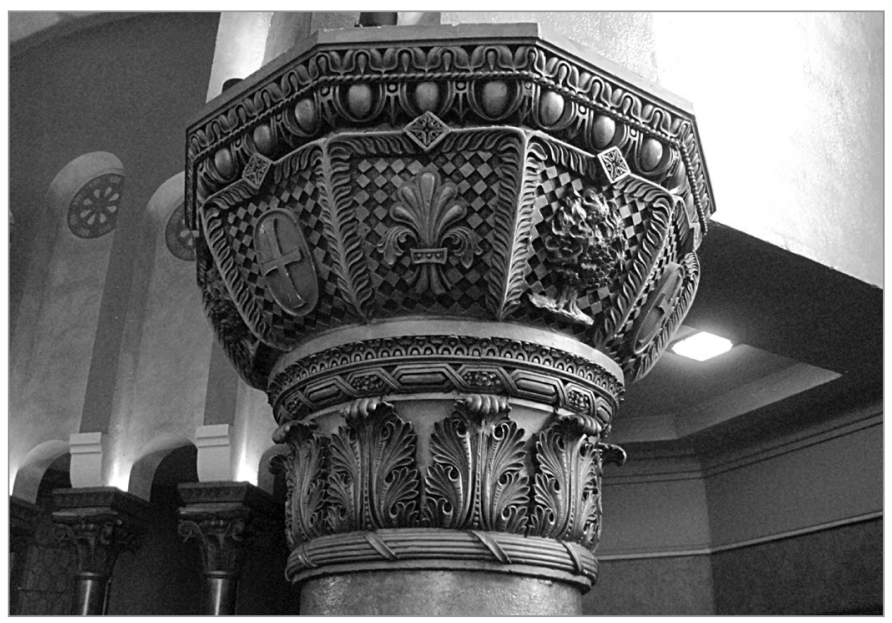

FIG. 10. DETAIL, BYZANTINE-INSPIRED CAPITAL ON GIANT ORDER SUPPORT COLUMNS, DOMINION-CHALMERS SANCTUARY. | NATALLE ANDERSON RATHWELL, 2013.

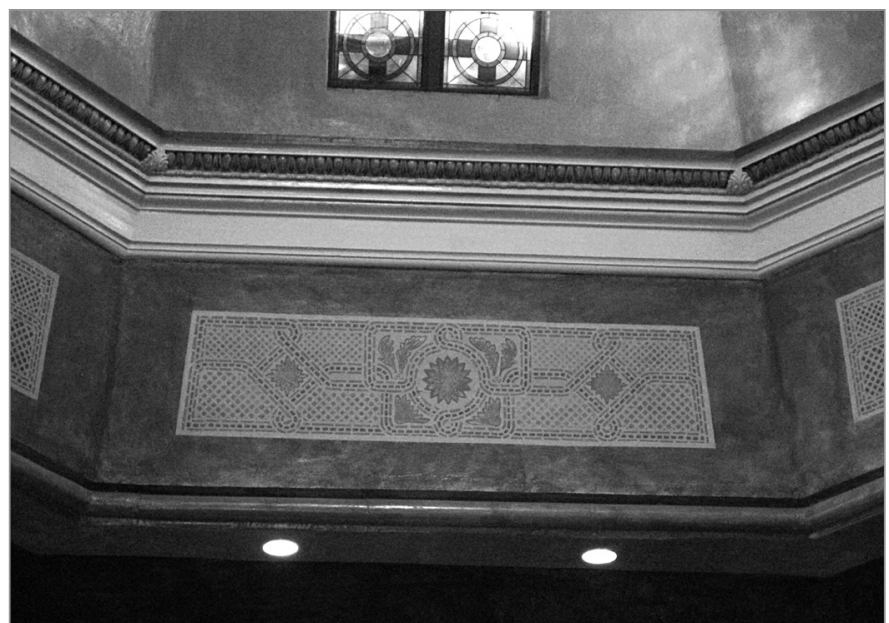

FIG. 12. ORIGINAL STENCIL WORK BELOW THE DOME, DOMINION-CHALMERS. | NATALIE ANDERSON RATHWELL, 2013. pleasing. Its strong, dynamic façade engages with the streetscape through its use of varied heights and protrusions, articulated stonework, and the tactile sense of the multiple stone surfaces. The building displays elevated craftsmanship in its interior and details, including in particular the Corinthian and Byzantine-inspired capitals and original stencil work above the entrances to the balcony and below the dome (figs. 9-12).

In terms of auditory significance, Dominion-Chalmers boasts excellent acoustics. Choral music, solo vocalists, and organ performances have long been a regular part of the church's worship program. "Acoustically it's very responsive and has clarity and resonance that can accommodate a powerful brass group, as well as a small early music group," states Roman Borys, artistic director for the Ottawa Chamber Music Festival. ${ }^{32}$

In a preliminary experiment to examine the acoustic qualities of Dominion-Chalmers, I had a speaker stand at the pulpit with a decibel meter while I occupied the back row of different locations in the sanctuary (fig. 13). For each test location, the speaker spoke in a regular conversational voice of between 65 and 79 decibels, followed by a "Sermon" voice of 80 to 85 decibels, maintaining a frontal orientation in each case. In all but one location I was able to clearly hear both the conversational and sermon levels of speech. In location 4, above and behind the speaker, only a few words were lost to an echo. To have my voice heard from the far reaches of the balcony by the speaker at the pulpit, conversely, required me to shout. I intend to repeat this exercise 


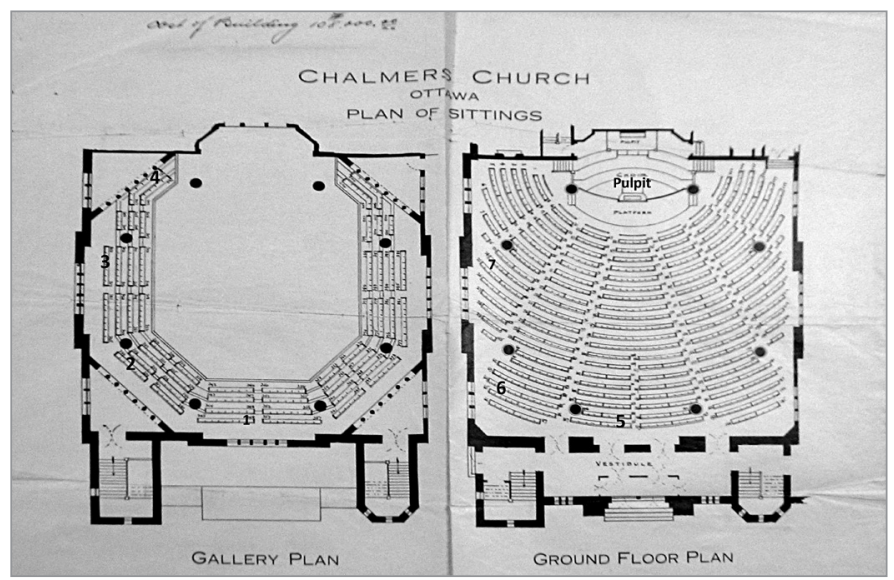

FIG. 13. PLAN OF PRELIMINARY ACOUSTIC TESTING, SHOWING LOCATION OF THE SPEAKER AT THE GROUND-LEVEL PULPIT AND SEVEN LOCATIONS OCCUPIED BY THE LISTENER. | SEATING PLAN COURTESY OF DOMINION-CHALMERS UNITED CHURCH ARCHIVES. NOTATIONS BY NATALIE ANDERSON RATHWELL.

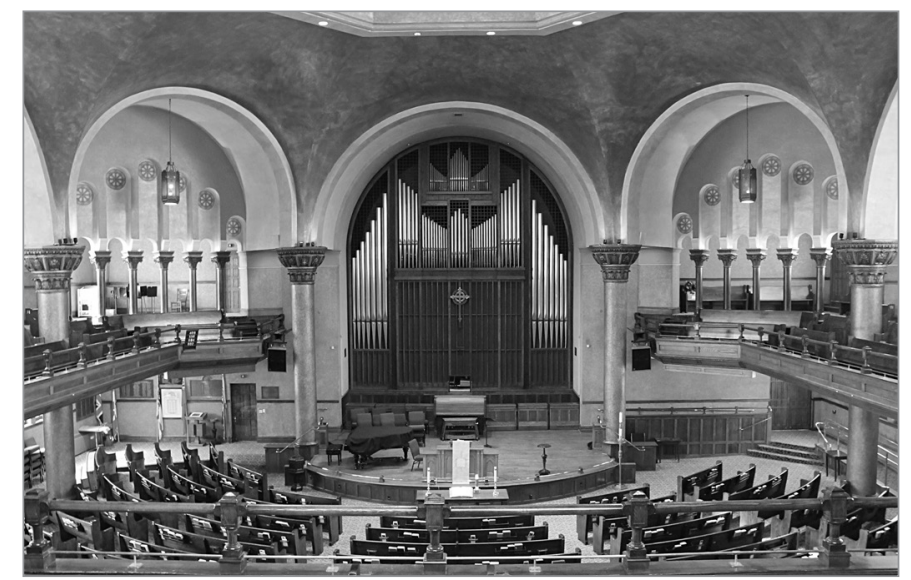

FIG. 14. VIEW TOWARD THE PULPIT, DOMINION-CHALMERS SANCTUARY. | NATALE ANDERSON RATHWELL, 2017. with two decibel meters, and under a variety of conditions, including having the room filled with people. Needless to say, the acoustics are excellent, and significantly better than many rooms purposebuilt for university teaching.

These characteristics of the church are the result of the architect's design capabilities, but also come out of the trend in Protestant church building toward amphitheatrical seating arrangements popularized in the late nineteenth century. ${ }^{33}$ Configurations could include curved (not at right angles) horse-shoe arrangements of pews, orienting worship toward one corner of the sanctuary, incorporating gallery seating, and/or arranging pews in a fan shape and giving a slope to the floor, as seen in this case. ${ }^{34}$ These adaptations to church seating have roots as early as the Protestant Reformation and serve the requirements of Protestant worship, of which the most prominent are sight and sound. ${ }^{35}$ Candace Iron describes the need to cater to these requirements as follows:

In Anglican and Roman Catholic churches, the seating arrangements are not as essential, due to differences in the preaching methods.

Protestants (nonconformists] do not believe in a theological proof of God. Rather, they believe that theology is simply an explanation of faith itself. Because of that, a church is just a meeting place where people can talk about experiences of God through reading the Bible and speaking about the Christian experience. That kind of sermon necessitates that the congregation is able to hear and see the preacher. If those two necessities cannot be accommodated, then the church building is not successful as a nonconformist structure as it denies the very function of the church. ${ }^{36}$

Architect Alexander C. Hutchison notes in his description of the building that "the choir and pulpit will be on view from every seat in the auditorium and gallery" ${ }^{\prime 37}$ (fig. 14).

\section{AESTHETIC VALUE - ROMANESQUE AND BYZANTINE REVIVAL}

Toward the end of the nineteenth century, concern was voiced by certain church designers that the quality of structures incorporating auditorium plans, and especially galleries, was not particularly high. ${ }^{38}$ Aesthetic and structural elements were often less than elegantly combined and books of church designs proposed a variety of remedies. James Cubitt, for example, advocated for the minimization of problematic columns, and for centrally planned spaces. His Church Designs for Congregations of 1870 provides numerous examples of Byzantine models as well as mosques to this end. ${ }^{39}$

As part of establishing a defined visual identity, many builders of Protestant churches followed the influential example of American architect Henry Hobson Richardson [1838-1886] and his "Richardsonian Romanesque." Dominion-Chalmers is one such example. Richardson's monumental structures typically demonstrate Romanesque features such as heavy masonry exteriors, polychrome stonework, rounded arches, and sculptural references. Several prominent examples of Richardson's work, such as the Trinity Church Project (published in 1873) and Trinity Church, Boston (18721877), include centralized interiors, incorporating domed and decorated spaces. ${ }^{40}$ While Richardson's churches, with one exception, do not employ amphitheatrical seating plans, his combination of a Romanesque exterior with centrally planned interior was readily adaptable to 


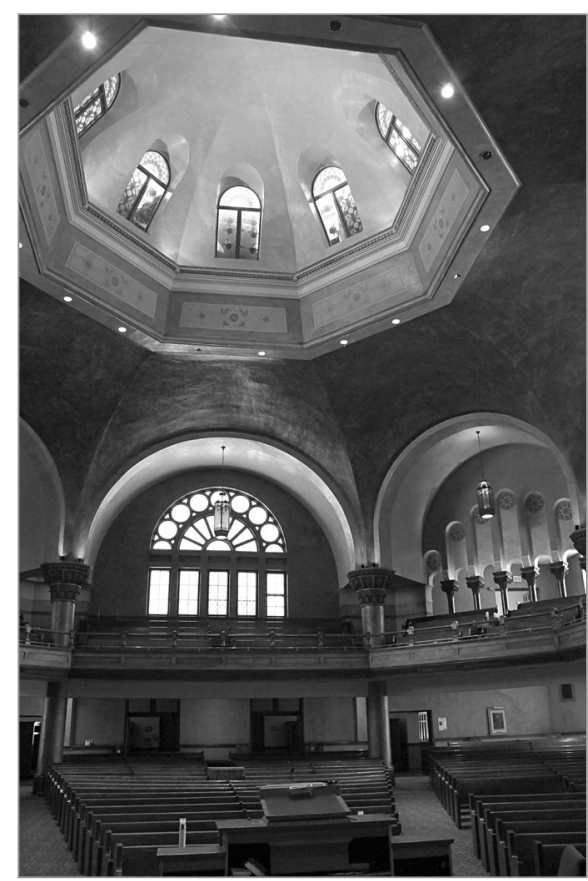

FIG. 15. VIEW OF THE DOME FROM BEHIND THE PULPIT, DOMINION-CHALMERS. | NATALIE ANDERSON RATHWELL, 2017.

this end. ${ }^{41}$ Hutchison's Erskine Presbyterian (Montreal, 1893-1894, renovated in 1938 and 2007) is one such example, as are Milton Earl Beebe's St. Thomas Anglican Church (St. Catharines, ON, 1877), and First Presbyterian Church (Chatham, ON, 18941895), where Thomas John Rutley used Richardson's style and an amphitheatrical plan, in a space termed Byzantine, to great effect. ${ }^{42}$

Dominion-Chalmers, built between 1912 and 1914, is a late example of the Romanesque/Byzantine Revival trend in church architecture. The church is noteworthy for its especially cohesive design and much more direct and integrated referencing of Byzantine-style details in the sanctuary. Where Chatham was described as Byzantine, its centralized plan, use of vaulting, and window arrangement only subtly refer to this architectural lineage. ${ }^{43}$ Dominion-Chalmers on the other hand explicitly references Byzantine architectural details throughout (fig. 15) in a similar, though more sparse manner to Toronto's St. Anne's Anglican Church (Ford Howland, 1907-1925). ${ }^{44}$ Features include the dome pierced with windows, the use of barrel vaults relieving and enclosing the walls pierced with windows, the use of screens of columns at the second-storey level, the effect of openwork created by the checkerboard pattern on the capitals of the giant order columns, the motif of the octagon, and the narthex extending across the length of the façade. While many of these details can be seen to take well known sources such as Hagia Sophia and Hagia Irene (both in Istanbul, Turkey) or San Vitale (Ravenna, Italy), as a general point of reference, whether Hutchison is here creating a general byzantinizing effect or referring to specific models for individual elements of his architectural composition is an area deserving of further scholarship.

\section{AESTHETIC VALUE - ARCHITECT ALEXANDER C. HUTCHISON}

Alexander C. Hutchison [1838-1922] is a monumental figure in the architectural landscape of Canada. ${ }^{45} \mathrm{His}$ role in the history of Chalmers Presbyterian Church is a strong argument for the building's aesthetic heritage value. He was born in Montreal, and the greatest body of his work is located there. Hutchison's study was primarily self-directed. ${ }^{46}$ He trained as a stonecutter from the age of twelve and took drawing classes at the Mechanic Institute. ${ }^{47}$ In his early twenties he became the head of stonecutting for Christ Church Cathedral in Montreal, and next for the entire East Block of the Parliament Buildings. Hutchison continued to pursue training and traveled to see architecture in parts of the United States. Over the course of his career he was the head of multiple successful architectural firms, including Hutchison and Steel, Hutchison and Wood, and Hutchison, Wood and Miller. ${ }^{48} \mathrm{He}$ had a hand in creating approximately 67 institutional or ecclesiastical works (including 33 churches), 69 commercial or industrial works, and 89 residential works. He is credited with creating the first ice palace for Montreal's Winter Carnival and became internationally famous for these. ${ }^{49} \mathrm{~A}$ list of Hutchison's other accomplishments include his roles as:

one of the founders and President of the Province of Quebec Association of Architects ... [lecturer] in the Presbyterian College on Ecclesiastic Architecture . . . an elder of the Presbyterian Church . . . one of the original members of the Royal Canadian Academy of Art and . . . its vice-president until 1907 ... . [he] had two sons and one daughter. . . he served as a school trustee, councillor and [municipal] mayor. He was a volunteer fireman and took an active part in the volunteer militia . . . he took part in the Fenian raids in 1866 and 1870 and was decorated for his service. Alexander was . . President of the Canadian Branch of the Caledonian Curling Club, the Montreal Caledonia Curling Club, and the Heather Club of Westmount . . . He was a life governor of the Montreal General Hospital, of the Protestant Hospital for the Insane, governor of the Western Hospital and President of the Protestant House of Industry and Refuge he never tasted alcohol nor tobacco and, according to all who knew him, he was a highminded gentleman of the old school. ${ }^{50}$

He died at 83

Hutchison's role as architect is integral to the construction of Chalmers Presbyterian Church, and also to the history of the congregation. The architect's brother William was a founding member of the Bank Street congregation and a member of the original building committee. ${ }^{51}$ Hutchison was commissioned for the plans for the original Bank Street church in 1869 and was commissioned again to plan a new 
Sunday school for the same site in 1889 . 52 In 1912, he prepared the plans for the new Chalmers Presbyterian. ${ }^{53}$ This time it was his nephew, George N. Hutchison, who was secretary of the building committee. No other architects are mentioned in relation to the congregation within the lifespan of Hutchison's career.

Building committee members for the new Chalmers Presbyterian were sent to Montreal to look at other churches designed by Hutchison. While they are not explicitly referenced, almost certainly the committee saw St. Andrew's Presbyterian Church (1908-1909, Stanton Street, Westmount) lost to fire in 1965, and Erskine Presbyterian, later called Erskine and American United. Now decommissioned, Erskine and American is a music venue and a part of the Musée des BeauxArts and, although greatly reworked, remains a testament to Hutchison's design and acoustics. ${ }^{54}$ Dominion-Chalmers, as a late example of the Romanesque/ Byzantine Revival style of Protestant worship architecture is aesthetically valuable for its cohesion. It is a late flowering in a nationally significant career.

\section{CONCLUSIONS}

As a work of architecture, DominionChalmers United Church is a repository of heritage value. Character-defining elements that must be preserved in order to maintain this value include the exterior masonry, stonework details, towers, and main entry. Inside, maintenance of the column capitals, dome, stencil work, woodwork (including the pews and their arrangement), and general state of repair of the plaster is essential. The original leaded windows and stained-glass windows preserved from Dominion are also significant to the churches' combined history. In addition to physical maintenance, to preserve Dominion-Chalmers' intangible values, the building must be allowed to be a vital presence in the community even if it should cease to serve a religious purpose. Simultaneously, the building's spiritual heritage should be preserved, either in its current living tradition or an archival one. The restoration work between 2000 and 2004 cost the church a total of three million dollars. In 2006 the city recognized the quality of the restoration and the addition, sympathetic to the original exterior, with an Ottawa Architectural Conservation Award of Excellence..$^{55}$ Carleton University's plans for the building, should the purchase be completed, include its "use as a multipurpose performance space for Carleton students and faculty, and as a new hub for artists and community groups." ${ }^{56}$ With such a restoration as a starting point, and the possibility of renewed relevance to the wider community through a purchase by Carleton University, there is reason to be hopeful that Dominion-Chalmers is on a positive track to preserving its heritage value.

\section{NOTES}

1. I would like to thank my supervisor Dr. Malcolm Thurlby (York University), Dr. Peter Coffman (Carleton University), and David C. Hayman (Chair of Council, Dominion-Chalmers United) for their valuable insight and assistance with this project.

2. "Section 3," Historical Report of Chalmers United Church, Ottawa, February 1934, box 9/ $\mathrm{DCH} / 2$, Dominion-Chalmers papers, Ottawa, ON, City of Ottawa Archives. Hereafter referred to as: Historical, box 9/DCH/2.

3. A case can be made for the heritage value of the later additions which cater especially to community functions. The present paper will limit itself to the scope just mentioned, however, for which there exists an especially compelling case.

4. Smith, Julian S., 1989, Draft Report: Property Evaluation, Dominion Chalmers United Church, Dominion Chalmers United Church Priorities and Planning Committee, Ottawa, ON, DominionChalmers United Church Archives, p. 3.
5. Hutchison, Alexander Cowper, "Architect's Notes to the Building Committee," box N13, Bank Street/Chalmers Presbyterian manuscripts, Ottawa, ON, Dominion-Chalmers United Church Archives. Hereafter referred to as: Hutchison, "Notes to the Building Committee," box N13.

6. Smith, Draft Report, p. 3.

7. Richardson, Peter and Douglas Richardson, 2007, Canadian Churches: An Architectural History, Richmond Hill, ON, Firefly Books, p. 261.

8. Nyenhuis, Michael (ed.), 2009 [4 ${ }^{\text {th }}$ ed.], "Dominion-Chalmers United Church," A Faith Journey; Photo History of the Churches of Ottawa Presbytery, Ottawa, ON, The United Church of Canada, p. 60.

9. "Section 2(a)," Historical, box 9/DCH/2.

10. Id.

11. "Section 2(b)," Historical, box 9/DCH/2.

12. "Section 3," Historical, box 9/DCH/2.

13. The seating capacity of Dominion-Chalmers sanctuary is today estimated to be $900-950$, based on removal of pews to create wheelchair access, and increased requirements for personal space. Conversation with David Hayman, Chair of Council, Dominion-Chalmers United Church, 2016.

14. "Anniversary Vignette \#8, The Very Rev. Dr. John W. Woodside; Our History," Dominion-Chalmers United Church, [http://www.dc-church.org/index. php? page =Vignette8], accessed November 15, 2012.

15. "Presbyterian Church in Canada; The Vote in Congregations; Entering 'The United Church of Canada,'" box 9/DCH/2, Dominion-Chalmers papers, Ottawa, ON, City of Ottawa Archives.

16. Bulletin for Dominion-Chalmers Official Inauguration Services, 1956, box 9/DCH/2, Dominion-Chalmers papers, Ottawa, ON, City of Ottawa Archives. Hereafter referred to as: Bulletin, 1956, box 9/DCH/2.

17. "Dominion United Enters $110^{\text {th }}$ Year," Montreal Gazette, vol. CLXVI, no. 272, box 9/DCH/2, Dominion-Chalmers papers, Ottawa, ON, City of Ottawa Archives.

18. Bulletin, 1956, box 9/DCH/2.

19. Hilborn, Audrey, 1976, "A Sketch History of Dominion United Church," box 9/DCH/2, Dominion-Chalmers papers, Ottawa, ON, City of Ottawa Archives. 
20. "The Building," St. Andrew's Presbyterian Church, Ottawa, ON, [http://www.standrewsottawa.ca/who-we-are/the-building], accessed November 15, 2012.

21. Hilborn, "A Sketch History," 1976; and "Letter from Lady Naomi Slater Heydon," box 9/DCH/2, Dominion-Chalmers papers, Ottawa, ON, City of Ottawa Archives.

22. Bulletin, 1956, box 9/DCH/2.

23. "2012 Anniversary Vignette \#6 Disastrous Fire at Dominion United Church," DominionChalmers United Church, [http://www.dcchurch.org/index.php? page =Vignette6], accessed November 15, 2012.

24. These were: Barbara A. Hayman and Marny Emmerson. Conversation with Barbara Hayman, November 2012 (deceased, aged 96, August 2016).

25. Newspaper clipping, "Apathy May Close City Church," 1969, box 9/DCH/2, DominionChalmers papers, Ottawa, ON, City of Ottawa Archives.

26. Canadian Register of Historic Places; Writing Statements of Significance, 2006, Winnipeg, $M B$, Historic Places Program Branch, National Historic Sites Directorate, Parks Canada, p. 12, [http://www.historicplaces.ca/media/5422/sosguideen.pdf].

27. Ibid.

28. Id., p. 13.

29. Ibid.

30. Conversations with David Hayman, Chair of Council, Dominion-Chalmers United Church, 2016. Also, Carleton Newsroom, December 5 , 2017, "Carleton University Enters into Negotiations to Purchase Dominion-Chalmers United Church," Ottawa, ON, Carleton University, [https://newsroom.carleton. ca/2017/12/05/dominion-chalmers-decision/], accessed December 10, 2017

31. Canadian Register, Parks Canada, p. 12.

32. Borys, Roman, quoted by Peter Robb, January 19, 2016, "Dominion-Chalmers Seeks New Path: Is a Community Centre for the Arts in Landmark Church's Future?" Ottawa, ON, The Ottawa Citizen, [http://ottawacitizen.com/ entertainment/local-arts/dominion-chalmersseeks-new-path-is-a-community-centre-forthe-arts-in-landmark-churchs-future], accessed December 10, 2017

33. Hucker, Jacqueline, 1988, "The Cardston Temple, Alberta, and Nonconformist Form," Journal of the Society for the Study of Architecture in Canada, vol. 23, no. 2, p. 5556
34. Halgren Kilde, Jeanne, 2002, When Church Became Theatre: The Transformation of Evangelical Architecture and Worship in Nineteenth-century America, New York, NY, Oxford University Press, p. 1113.

35. Ibid. Also, Iron, Candace, 2005, "Thomas John Rutley: A Presbyterian Church Designer," Journal of the Society for the Study of Architecture in Canada, vol. 30, no. 2, p. 42.

36. Iron, "Thomas John Rutley," p. 42. Iron refers here to Alan Gowans, 1958, Looking at Architecture in Canada, Toronto, ON, Oxford University Press, p. 124.

37. Hutchison, "Notes to the Building Committee," box N1-3.

38. Cubitt, James, 1870, Church Design for Congregations: its Developments and Possibilities, London, Smith, Elder and Co. On page 75 , arguing for better cohesion in church plans, Cubitt writes: "To say that a church has galleries, is, with most people, quite enough to condemn it. In this statement they find sufficient clue to its artistic character. They know, by experience, to what sort of architecture galleries are usually joined, and they have no wish for a closer acquaintance with it. And, in truth, it rarely happens, in modern work, that the gallery is anything but an eyesore and a detriment to the building. Seldom is it accepted as one of the main conditions of the case, and incorporated into the very essence of the design. The idea that generally suggests itself is that it was forced in against the architect's will ... And yet some of the finest ancient churches in existence are galleried ones."

39. Cubitt, Church Design for Congregations, p. 52.

40. Iron, "Thomas John Rutley," p. 40; Ochsner, Jeffery Karl, 1996, H.H. Richardson: Complete Architectural Works, Cambridge, MA, The MIT Press, p. 100-101, 114123

41. Ochsner, H.H. Richardson, p. 357. A late work of H.H. Richardson's career, Immanuel Baptist Church, 1884-1886, 187 Church Street, Newton, MA, demonstrates a fan-shaped seating arrangement with four rows of curved pews. It is noted, however, that only some of these are original, following a fire in the 1960s.

42. Iron, Candace, 2006, "Why Such an Odd Plan? Milton Earl Beebe's St. Thomas Anglican Church, St. Catharines, Ontario," Journal of the Society for the Study of Architecture in Canada, vol. 31, no. 2. Also, Iron, "Thomas John Rutley," p. 41.

43. Iron, ibid. Inset quotation: The Chatham Dailey Planet, April 9, 1892.

44. Richardson, Canadian Churches, p. 259
45. Griscti, Verity and Joshua Hull (eds.), n.d., "Hutchison, Alexander Cowper," Biographical Dictionary of Architects in Canada 18001950, n.p., [http://dictionaryofarchitectsincanada.org/architects/view/1535], accessed November 15, 2012.

46. Gersovitz, Julia, "Alexander Cowper Hutchison," The Canadian Encyclopedia, Historica Canada, [http://www.thecanadianencyclopedia.com/ articles/alexander-cowper-hutchison], accessed November 17, 2012.

47. "Alexander Cowper Hutchison," City of Westmount, last modified March 26 , 2007, [https://web.archive.org/ web/20120602141227/http://www.westmount. org/page.cfm?Section_ID =3\&Menu_Item _ $I D=270 \& M e n u \_$Item_Sub $=296 \&$ Menu_Item Fourth =314], accessed November 17, 2012.

48. Griscti and Hull, "Hutchison, Alexander Cowper," op. cit.

49. Ibid. Also, Gersovitz, "Alexander Cowper Hutchison," op. cit.

50. "Alexander Cowper Hutchison," City of Westmount, op. cit.

51. Moore, Rev. William, The History of Bank Street Presbyterian Church, Ottawa, 18651911, Chalmers Presbyterian Church, 14, box N13, Bank Street/Chalmers Presbyterian manuscripts, Ottawa, ON, Dominion-Chalmers United Church Archives.

52. "Section 2(b)," Historical, box 9/DCH/2. The architect of Bank Street Presbyterian is not explicitly referred to in the minute book for the Bank Street Building Committee, but A.C. Hutchison's involvement, suggested by the above source, is highly likely.

53. Building Committee Minute Book, box N1-3, Bank Street/Chalmers Presbyterian manuscripts, Ottawa, ON, Dominion-Chalmers United Church Archives, p. 16

54. Laplace, Josée, 2011, "Rêve muséal : Étude de la patrimonialisation de l'église Erskine and American United à Montréal," Journal of the Society for the Study of Architecture in Canada, vol. 36, no. 2, p. 28-29, 34 .

55. Nyenhuis, "Dominion-Chalmers United Church," p. 60; and commemorative plaque, Dominion-Chalmers narthex/vestibule.

56. Carleton Newsroom, December 5, 2017, "Carleton University Enters into Negotiations to Purchase Dominion-Chalmers United Church," Ottawa, ON, Carleton University, [https:// newsroom.carleton.ca/2017/12/05/dominionchalmers-decision/], accessed December 10, 2017. 